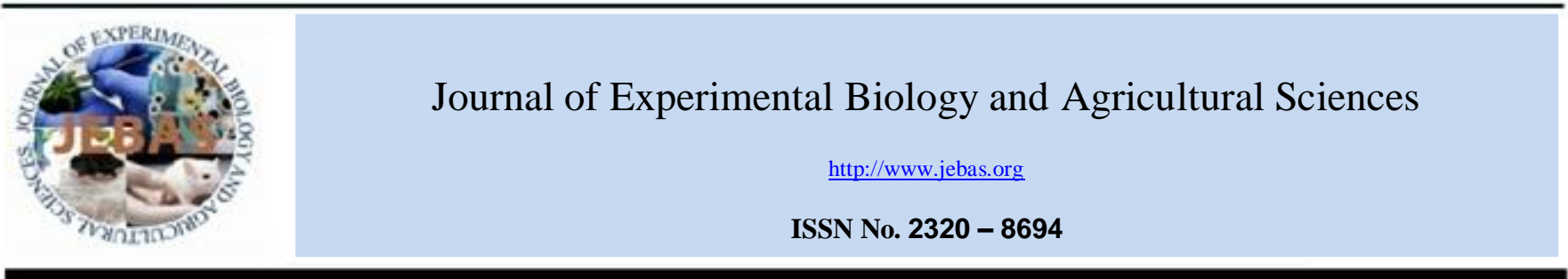

\title{
DECOLOURIZATION, DEGRADATION AND DETOXIFICATION OF DYE HOUSE EFFLUENTS BY A DEVELOPED BACTERIAL CONSORTIUM
}

\author{
Darshna K. Patel ${ }^{1}$, Devayani R. Tipre ${ }^{1}$, Shailesh R. Dave ${ }^{2 *}$
}

${ }^{1}$ Department of Microbiology and Biotechnology, School of Sciences, Gujarat University, Ahmedabad 380009, Gujarat, India.

${ }^{2}$ Xavier's Research Foundation, Loyola Centre for Research and Development, St. Xavier College Campus, Navrangpura, Ahmedabad 380009, Gujarat, India.

Received - February 20, 2019; Revision - March 26, 2019; Accepted - April 04, 2019

Available Online - April 10, 2019

DOI: http://dx.doi.org/10.18006/2019.7(2).211.221

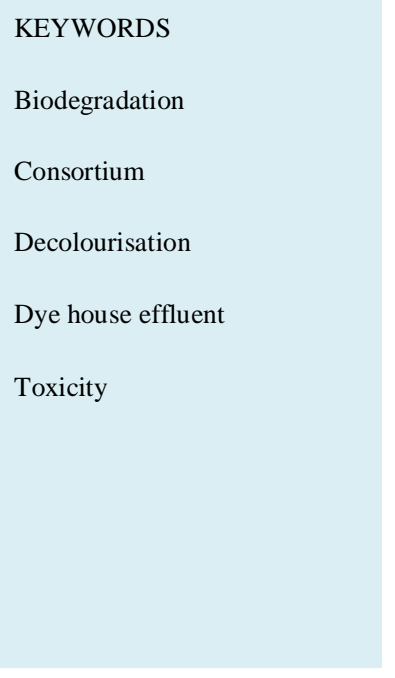

\begin{abstract}
Decolourization and degradation of two dye house effluents (DHEs) have been studied using a developed bacterial consortium. Batch experiments were optimized at shake flask level in terms of $\mathrm{pH}$, temperature, culture condition, carbon and nitrogen source. Bacterial consortium was found to be active between pH 6-10 and temperature $25-40{ }^{\circ} \mathrm{C}$ under static condition. Among different carbon and nitrogen sources studied, addition of sucrose, fructose, glucose and beef extract were found to support the degradation of both Effluent-2 and 3 (E-2, E-3). Decolourization and degradation profiles of E-2 and E3 DHEs were studied to optimize the treatment time. Reduction in BOD, COD and ADMI (American Dye Manufacturers' Institute) values were more than $95 \%$, which proved the treatment efficiency of the developed consortium against both the DHEs Moreover, FTIR and HPLC spectral data analysis and enzyme induction pattern confirmed biodegradation of all the DHEs. Intracellular azoreductase, NADHDCIP reductase and laccase played significant role in degradation. Phytotoxicity and microbial toxicity were reduced in the range of $70-80 \%$ and $40-46 \%$, respectively. This results indicated production of non-toxic metabolites. The study gave significant information for the bio-treatment of DHEs containing various heavy metals using a developed bacterial consortium.
\end{abstract}

* Corresponding author

E-mail: shaileshrdave@yahoo.co.in, srdave@gujaratuniversity.ac.in (S.R. Dave)

Peer review under responsibility of Journal of Experimental Biology and Agricultural Sciences.

Production and Hosting by Horizon Publisher India [HPI] (http://www.horizonpublisherindia.in/).

All rights reserved.
All the article published by Journal of Experimental Biology and Agricultural Sciences is licensed under a Creative Commons Attribution-NonCommercial 4.0 International License Based on a work at www.jebas.org.

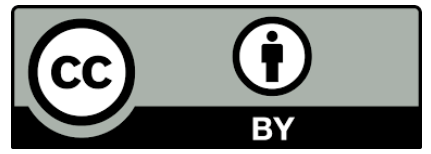




\section{Introduction}

Water pollution is one of the major areas of concern since last few decade as it has a major impact on all life forms along with aquatic life. Among the major sources of pollutes, coloured waste water generated from the dye houses and textile industries are the most common one (Vikrant et al., 2018). Both these kind of industries consume a huge amount of water and generate coloured effluents. Tehrani-Bagha et al. (2010) reported that among all industrial sectors, coloured wastewater generating industries are found to be the most polluting. Wastewaters containing colours are easily visible and hence pose aesthetic pollution problems. Dye house effluents (DHEs) generally contain dark coloured water along with heavy metals (chromium, copper, molybdenum, zinc, etc.), COD, BOD, TOC, TDS and TSS (Patel et al., 2015). Such metal containing pollutants are known to be hazarus for living beings ( $\mathrm{Li}$ et al., 2015). Moreover, some portion of dyes are not recovered during the downstream processing and hence dye house wastes are more concentrated as compared to the textile wastewater because textile waste waters get diluted during the washing process of clothes (Patel et al., 2015). Physical and chemical treatment methods are not always possible as they are more costly and practically ineffective. Generation of huge amount of sludge is another problem in such physicochemical treatment methods including advance oxidation process and other conventional treatment methods (Vikrant et al., 2018). Biodegradation is an attractive tool for the treatment of such wastes as it is cost effective and ecofriendly in nature (Stolz, 2001; Shah et al., 2013; Cerron et al., 2015; Raper et al., 2018). Use of various biological organisms including bacteria, fungi, yeast, algae and plants have been studied for their remediation potential (Dave \& Dave, 2009; ZabłockaGodlewska et al., 2015; de Almeida \& Corso, 2016; Alizadeh et al., 2017; Ghosh et al., 2017; Swati et al., 2017). Use of consortial system offer a great number of benefits including degradation ability of more than one compound at a time along with cometabolic activities leading to mineralization of the pollutant compound (Forgacs et al., 2004; Khehra et al., 2005; Sheth \& Dave 2010; Bilal et al., 2018). Benefits of using consortium for bioremediation are well reported in the literature (He et al., 2004; Balapure et al., 2016; Patel et al., 2017a; Bilal et al. 2019).

Most of the research work has been focussing only on pure dye or only one industrial effluent and that too mainly the textile wastewater or simulated wastewater, but not the actual DHEs. Different isolates and consortia are reported for degradation of individual dyes or waste. DHEs contain high organic load, high ADMI value, dark colour and presence of toxic metals (Patel et al. 2015). No data are available for treatment of more than one dye containing wastes with developed single bacterial consortium. Keeping these points in consideration bacterial consortium was developed and investigated for decolourization and degradation of two different diverse DHEs. Further, analysis of effluent detoxification was carried out to ensure the safty of the treatment procedure. Present study would be the base for the development of waste water treatment protocol for diverse group of dye containing industrial effluents.

\section{Materials and Methods}

\subsection{DHEs, media and chemicals}

Two DHEs designated as E-2 and E-3 were procured from Apex dye stuff industries located in Vatva GIDC industrial estate, Ahmedabad, Gujarat, India. Both the effluents were containing mixture of various azo dyes and metals as during that period, only metal complex azo dyes were manufactured by the industry. Treatment of DHEs was carried out in triplicates using 1:10 diluted DHE in Bushnell and Haas (BH) medium containing $(\mathrm{g} / \mathrm{L}): \mathrm{K}_{2} \mathrm{HPO}_{4}, 1.0 ; \mathrm{KH}_{2} \mathrm{PO}_{4}, 1.0 ; \mathrm{NH}_{4} \mathrm{NO}_{3}, 1.0 ; \mathrm{FeCl}_{3}, 0.05$; $\mathrm{CaCl}_{2}, 0.02 ; \mathrm{MgSO}_{4}, 0.2$ and $0.5 \%$ (w/v) yeast extract; $\mathrm{pH} 7.4 \pm 0.2$ in a $100 \mathrm{~mL}$ Erlenmeyer flasks containing $50 \mathrm{~mL}$ of DHE system comprising of $10 \%(\mathrm{v} / \mathrm{v})$ activated inoculum $\left(3 \times 10^{8}\right.$ cells $\left./ \mathrm{mL}\right)$. The preparaed system was kept at $35 \pm 2{ }^{\circ} \mathrm{C}$ temperature and static incubation condition. ABTS (2,2- azinobis (3ethylbenzothiazolin-6-sulphonic acid)), NADH (nicotinamide adenine dinucleotide hydrogen), tartaric acid, n-propane, Ltyrosine and other chemicals used in the study were of analytical grade from HiMedia Laboratories, India. Microbial cultures of Azotobacter sp. and Pseudomonas aeruginosa were obtained from the departmental culture collections.

\subsection{Bacterial consortium}

An indegeneous bacterial consortium was enriched from a dye polluted site as described in the earlier report (Patel et al., 2017a) and maintained in dye containing nutrient broth at $8 \pm 2{ }^{\circ} \mathrm{C}$ used for further use. Bacteria isolated on nutrient agar plate from the developed consortium were identified on the basis of $16 \mathrm{~S}$ rRNA gene sequence analysis at Chromous Biotech, Bangaluru, India. All the five isolates were added in equal proportion.

\subsection{Physico-chemical analysis of DHEs}

Analysis of DHEs for $\mathrm{pH}$, chemical oxygen demand (COD), biochemical oxygen demand (BOD), total dissolved solids (TDS) and total suspended solids (TSS) before and after treatment were carried out according to standard methods for water and wastewater analysis (Eaton et al., 1998).

\subsection{Optimization of DHEs decolourization}

Decolourization of DHEs was optimized using various parameters such as $\mathrm{pH}$ (4-12), temperature $\left(25-55^{\circ} \mathrm{C}\right)$, culture condition (static and shaking), carbon and nitrogen supplement in $\mathrm{BH}$ medium with $0.5 \%(\mathrm{w} / \mathrm{v})$ glucose, sucrose, lactose, maltose, mannitol, fructose, starch, yeast extract, peptone and beef extract. Decolourization profile of DHEs was studied at an interval of 
every $6 \mathrm{~h}$ until decolourization remained constant. Decolourization rate was calculated in terms of percent decolourization per hour (Patel et al. 2017b).

\subsection{Analysis of colour removal}

Decolourization of DHEs was measured by ADMI value calculation using Tristimulus filter method (Eaton et al., 1998) and comparison of UV-Vis spectra of DHEs before and after treatment. ADMI removal was calculated using Equation 1.

$\%$ ADMI removal $=\frac{(\text { Initial ADMI }- \text { Final ADMI })}{\text { Initial ADMI }} \times 100$

Where initial ADMI value at $0 \mathrm{~h}$ and the final ADMI value after a particular reaction time.

\subsection{Cell free extract preparation}

Cells from activated consortium were harvested by centrifugation at $8000 \mathrm{~g}$ for $10 \mathrm{~min}$. The supernatant obtained after centrifugation was directly used as a source of extracellular enzymes. The harvested cells were homogenized after suspending in $50 \mathrm{mM}$ potassium phosphate buffer at $\mathrm{pH} 7.4$, and sonicated (Sartrious, Germany) at an amplitude of $70 \%$ with ten strokes each of $30 \mathrm{~s}$ with a 2 min interval at $4{ }^{\circ} \mathrm{C}$ followed by centrifugation at $10000 \mathrm{~g}$ for $20 \mathrm{~min}$ at $4{ }^{\circ} \mathrm{C}$ to remove the cell debris (Patel et al., 2017a). The extra- and intracellular fractions were used as a crude enzyme for respective extracellular and intracellular enzyme assays. Reading of triplicate experiments were used for statistical analysis.

\subsection{Enzyme assay}

Oxidoreductive enzymes including lignin peroxidase (LiP), laccase, tyrosinase, azoreductase (Azo) and NADH-DCIP reductase (NADHDCIP red) from intracellular as well as extracellular fractions were studied for their induction pattern in decolourization of DHEs. Azoreductase (Khan et al., 2014), NADH-DCIP reductase (Lade et al., 2012), Laccase (Shah et al., 2012; Agrawal et al., 2014) and Tyrosinase (Kadam et al., 2011) enzymes activities were determined by standard protocole. One unit of reductive enzyme activity was defined as the amount of enzyme required to reduce $1 \mu \mathrm{M}$ substrate per minute. One unit of oxidative enzyme was defined as the amount of enzyme to increase 1.0 absorbance unit under standard assay conditions.

\subsection{Analysis of biodegradation}

The untreated and treated DHEs were centrifuged at 10,000 g for 10 min and supernatants were extracted using double volumes of ethyl acetate, and dried on a rotary vacuum evaporator at $45{ }^{\circ} \mathrm{C}$. The extracted metabolites were subjected to FTIR and HPLC analysis. FTIR analysis was carried out in the range of $600-4000 \mathrm{~cm}^{-1}$ with 16 scan speed (Bruker, Germany). For HPLC analysis, extracted metabolites were dissolved in spectroscopy grade methanol and injected in a C18 column $(250 \mathrm{~mm} \times 4.6 \mathrm{~mm}, 5 \mathrm{~mm})$ equipped with dual wavelength detector by the isocratic method using LC solutions (Shimadzu, Japan). The mobile phase was methanol:water (70:30) with a flow rate of $1.0 \mathrm{~mL} / \mathrm{min}$ and with $15 \mathrm{~min}$ run time.

\subsection{Phytotoxicity}

Phytotoxicity was carried out at ambient temperature using Phaseolus mungo. Ten seeds were irrigated separately by providing $5 \mathrm{~mL}$ of distilled water (as a control), untreated and treated DHEs. The effect of individual treatment on growth was assessed by measuring percent germination, plumule length and radical length after 10 days (Patel et al., 2015).

\subsection{Microbial toxicity}

The microbial toxicity of untreated DHEs and metabolites obtained after treatment was carried out using Azotobacter sp. and Pseudomonas aeruginosa (Patel et al., 2017b) and the mean of inhibition zone after $24 \mathrm{~h}$ of incubation at $35 \pm 2^{\circ} \mathrm{C}$ was recorded.

\section{Results and Discussion}

\subsection{DHEs characterization}

Characteristics of DHEs viz. E-2 and E-3 are shown in Table 1. Wide range of diversity in terms of $\mathrm{pH}$, TOC, COD, BOD, TDS,

Table 1 Physico-chemical characteristics of various DHEs.

\begin{tabular}{|c|c|c|c|}
\hline \multirow{2}{*}{ No. } & \multirow{2}{*}{ Parameters } & \multicolumn{2}{|c|}{ Characteristics of DHEs } \\
\hline & & E-2 & E-3 \\
\hline 1 & $\mathrm{pH}$ & 5.74 & 5.79 \\
\hline 2 & $\mathrm{TOC}(\mathrm{mg} / \mathrm{L})$ & 8322 & 8202 \\
\hline 3 & $\mathrm{COD}(\mathrm{mg} / \mathrm{L})$ & 23400 & 26000 \\
\hline 4 & BOD $(\mathrm{mg} / \mathrm{L})$ & 15757 & 15333 \\
\hline 5 & TDS (mg/L) & 231420 & 236850 \\
\hline 6 & $\mathrm{TSS}(\mathrm{mg} / \mathrm{L})$ & 404 & 412 \\
\hline 7 & $\operatorname{VSS}(\mathrm{mg} / \mathrm{L})$ & 136 & 280 \\
\hline 8 & NVSS (mg/L) & 268 & 132 \\
\hline 9 & $\mathrm{NH}_{3}-\mathrm{N}(\mathrm{mg} / \mathrm{L})$ & 868 & 854 \\
\hline 10 & Total nitrogen $(\mathrm{mg} / \mathrm{L})$ & 952 & 882 \\
\hline 11 & Colour (cu) & 1396000 & 1200000 \\
\hline 12 & ADMI & 107066 & 420107 \\
\hline 13 & Metal (mg/L) & & \\
\hline & $\mathrm{Cu}$ & 2.26 & 18.6 \\
\hline & $\mathrm{Zn}$ & 2.03 & 12.0 \\
\hline & $\mathrm{Fe}$ & 11.16 & 56.2 \\
\hline & $\mathrm{Cd}$ & 5.43 & 2.82 \\
\hline & $\mathrm{Cr}$ & 13.8 & 9.6 \\
\hline & $\mathrm{Ni}, \mathrm{Co}, \mathrm{Pb}$ & ND & ND \\
\hline
\end{tabular}


TSS, CU, ADMI and metal content was reported. The $\mathrm{pH}$ of the samples was found to be 5.7 alongwith narrow range of differences was observed for TOC, COD, BOD, TDS and TSS in case of both the effluents. However, samples were highly coloured and a remarkable differences was observed in case of ADMI value where ADMI value of 107066 and 420107 for E-2 and E-3, respectively. Both the effluents were orange coloured. Metal content was found as 2.26 and 18.6, 2.03 and 12.0, 11.16 and 56.2, 5.43 and 2.82, 13.8 and 9.6 for $\mathrm{Cu}, \mathrm{Zn}, \mathrm{Fe}, \mathrm{Cd}$ and $\mathrm{Cr}$ metals in $\mathrm{E}-2$ and $\mathrm{E}-3$, respectively. The BOD:COD ratio of untreated DHEs were 0.7 and 0.6 for E-2 and E-3, respectively. As per the literature, BOD:COD indicates the biodegradability of waste water (Dhall et al., 2012, Dave et al., 2015). If the BOD:COD ratio is $>0.5$, the waste is considered amenable to biodegradation, whereas, the ratio $<0.3$ indicates the presence of toxic compounds and hence needs to be stabilized prior to treatment. The obtained characterization of DHEs indicated the presence of coloured compounds and extent of biodegradability of samples.

\subsection{Identification of Bacteria from the consortium}

A developed bacterial consortium showed the presence of Pantoea ananatis (KM502538), Bacillus fortis strain E4 Pb3 (KM502537), Alcaligenes faecalis (KM502541), Brevibacillus parabrevis strain GRG (KM502542) and Bordetella trematum (KP751929) on the basis of $16 \mathrm{~S}$ rRNA gene sequencing of cultivable bacterial species. Sequence of the identified cultures are deposited and obtained Gen Bank accession numbers are mentioned with each organism in parenthesis (Patel et al., 2017b).

\subsection{Optimization of DHEs decolourization}

Influence of various parameters on decolourization is presented in Figure 1 A-D. The $\mathrm{pH}$ in the range of 6-10 was found to be the $\mathrm{pH}$ of choice for the study as the decolourization was more than $80 \%$. The developed inoculum showed considerable activity even at $\mathrm{pH} 5$ and 10 (Figure 1A). Effect of various incubation temperatures on biodecolourization of both the DHEs are shown in Figure 1B. The ADMI removal was found to be more than $96 \%$ for both the effluents at $35-40 \pm 2$ ${ }^{\circ} \mathrm{C}$ temperature. Both the DHEs showed 4 to 26 fold higher rate of \% ADMI removal at static incubation condition as compared to shaking condition (data not shown). This might be due to reduced air penetration at static condition than the shaking condition. The results
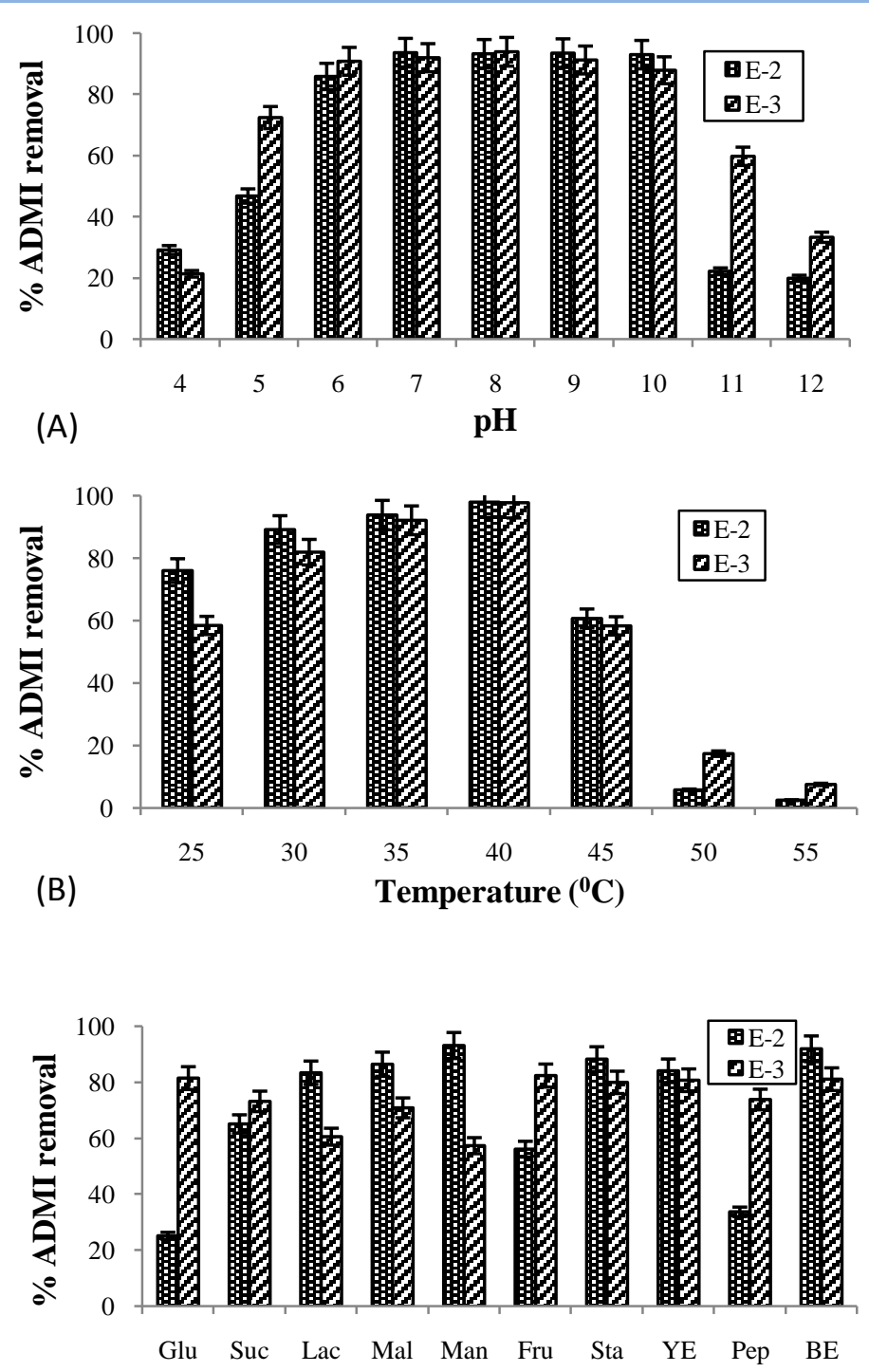

(C)

Carbon or Nitrogen source

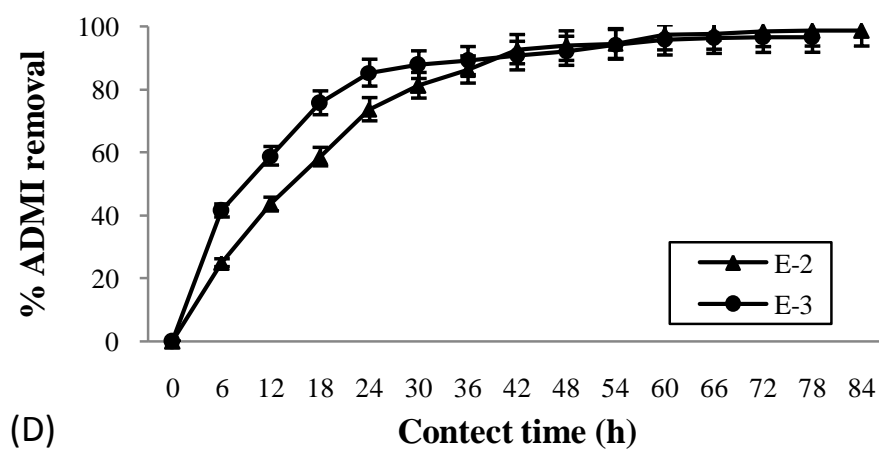

Figure 1 Effect of (A) pH (B) Temperature (C) Carbon and nitrogen source (D) Contact time on decolourization of DHEs. $(90 \mathrm{~mL}$ waste, $10 \mathrm{~mL}$ consortium, incubation at static conditions at $32 \pm 2{ }^{\circ} \mathrm{C}$ ) 
are in coordination with Pandey et al. (2007), where nonspecific reduction of azo dyes leading to colour removal under anaerobic conditions is explained.

Influence of addition of various carbon and nitrogen sources was also investigated and results are described in Figure 1C. The influence was found to be quite distinct in terms of DHEs under study. Addition of maltose was found to be the best for E-2; whereas, glucose was favouring the decolourization of E-3. The observed variation in the influence of added sugar could be explained based on the influence of particular effluents and presence of indegenous flora in the effluents. Addition of beef extract was found to be the choice as compared to yeast extract and peptone in the medium.

Decolourization profile in terms of incubation time showed more than $90 \%$ decolourization within $42 \mathrm{~h}$ (Figure 1D) for both the effluents. The average decolourization rates of first $42 \mathrm{~h}$ of treatment for E-2 and E-3 were 3.0 and $3.9 \%$ ADMI removal/h, respectively. Both the effluents showed fastest ADMI removal in first $6 \mathrm{~h}$ with 4.2 and $6.9 \%$ ADMI removal/h. Even in case of textile effluent $48 \mathrm{~h}$ are required to achieve $89 \%$ ADMI removal when BL-GG consortium was used (Kurade et al., 2012; Saratale et al., 2012).

\subsection{Analysis of treatment efficiency}

Treatment efficiency of the consortium for both the DHEs was studied in terms of COD, BOD, TOC, TDS, TSS and ADMI value reduction and results are listed in Figure 2. The DHEs showed increase in $\mathrm{pH}$, which rose from 7.4 to 8.4 after treatment.
Moreover, the treatment also resulted in 87 and $62 \%$ TOC reduction along with 95 and $84 \%$ COD reduction for E-2 and E-3, respectively. More than $98 \%$ BOD removal was observed from both the DHEs. Dissolved solids reductions were 87 and $78 \%$ for E-2 and E-3, respectively. Apart from this, the consortium showed $>99 \%$ metal removal as none of the metals was detected in any of the treated DHEs. In literature, reduction in high COD, ADMI and metal is reported for industrial effluent using bacterial consortium system by Patel et al. (2015). Decrease in COD, BOD, TOC, ADMI values of textile effluent was recorded after treatment using consortium AP (Lade et al., 2012) and the same parameters including reduction in solids is also documented in soil when plant and/or bacterial augmentation combinations were used. In the reported study, the presence of both plant and bacterial augmentation resulted in maximum $50-80 \%$ reduction (Khandare et al., 2013). Zhang et al. (2012) observed 40 and $84 \%$ of colour and COD reduction after anoxic-oxic treatment of a textile wastewater. Kurade et al. (2012) and Saratale et al. (2012) have observed 68 and $74 \%$ of BOD and COD reduction of a textile effluent, respectively though the initial BOD $(890 \mathrm{mg} / \mathrm{L})$ and COD $(3400 \mathrm{mg} / \mathrm{L})$ values were far less than the values in present effluents under study. More reduction in initial COD indicates the high rate of mineralization (Hassan \& Hawkyard 2002).

\subsection{Enzyme analysis}

All the studied enzymes were significantly induced both in intracellular and extracellular fractions (Figure 3) in case of both treated and untreated DHEs. Intracellular enzyme induction was more as compared to extracellular enzymes. The two enzyme families, azoreductases and laccases, showed a great potential in

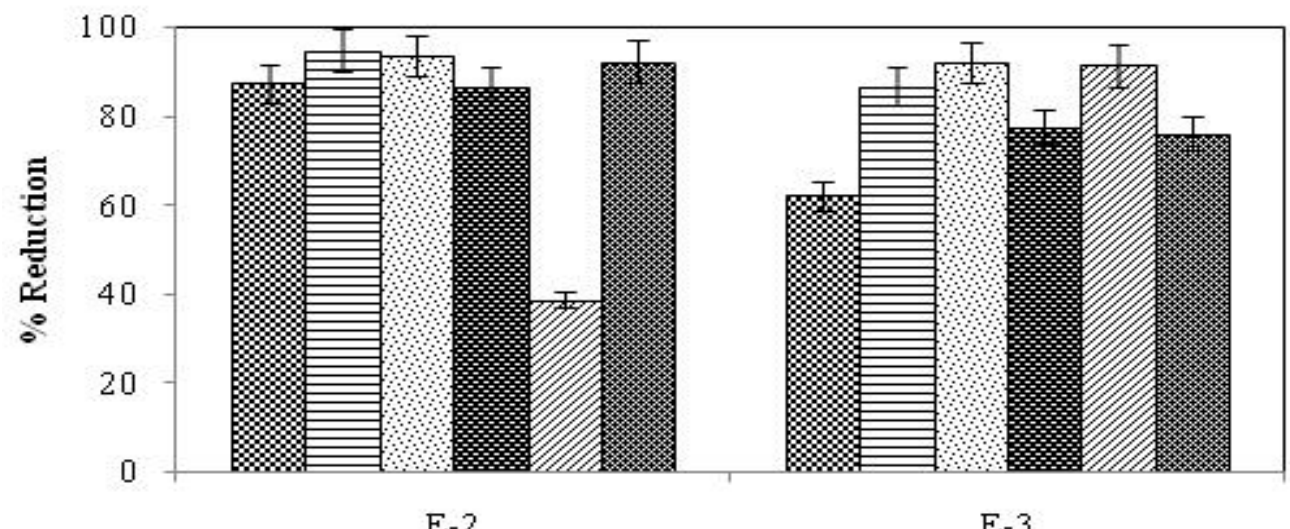

Effluent

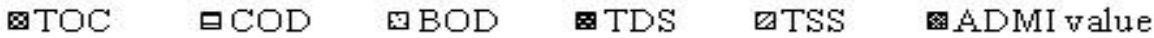

Figure 2 Percent reduction in TOC, COD, BOD, TDS, TSS and ADMI due to biological treatment of DHEs. $\left(90 \mathrm{~mL}\right.$ waste, $10 \mathrm{~mL}$ consortium, incubation at static conditions at $32 \pm 2{ }^{\circ} \mathrm{C}$ ) 


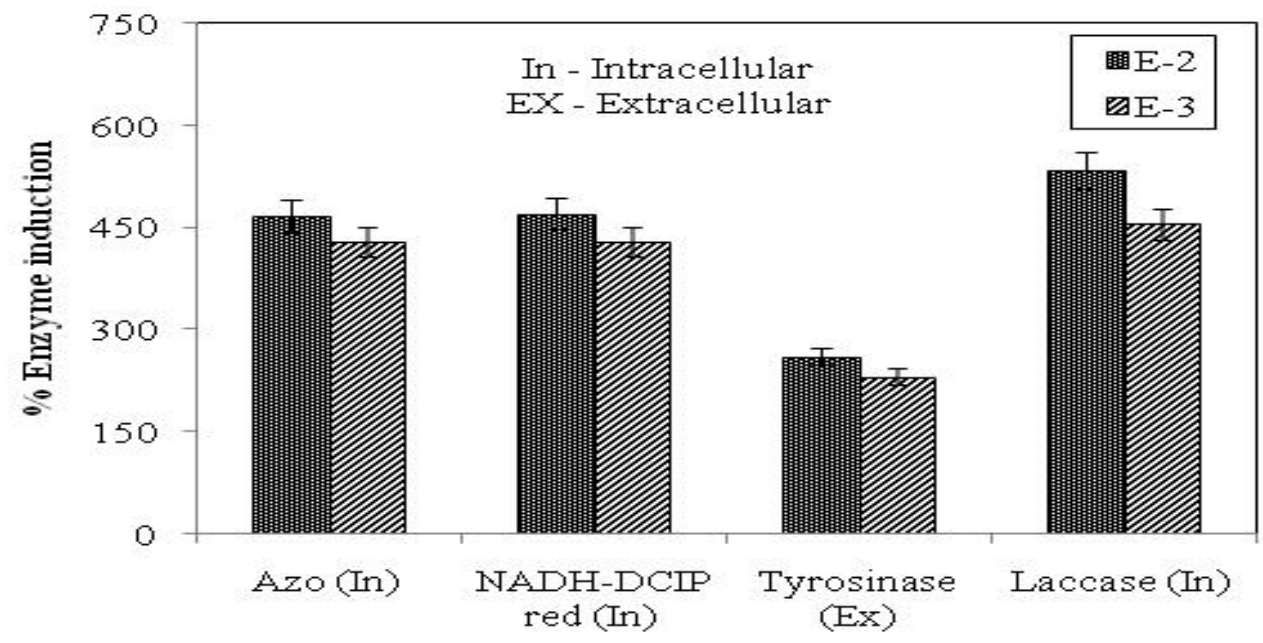

Figure 3 Induction of various enzymes by different DHEs. ( $90 \mathrm{~mL}$ waste, $10 \mathrm{~mL}$ consortium, incubation at static conditions at $32 \pm 2{ }^{\circ} \mathrm{C}$ )

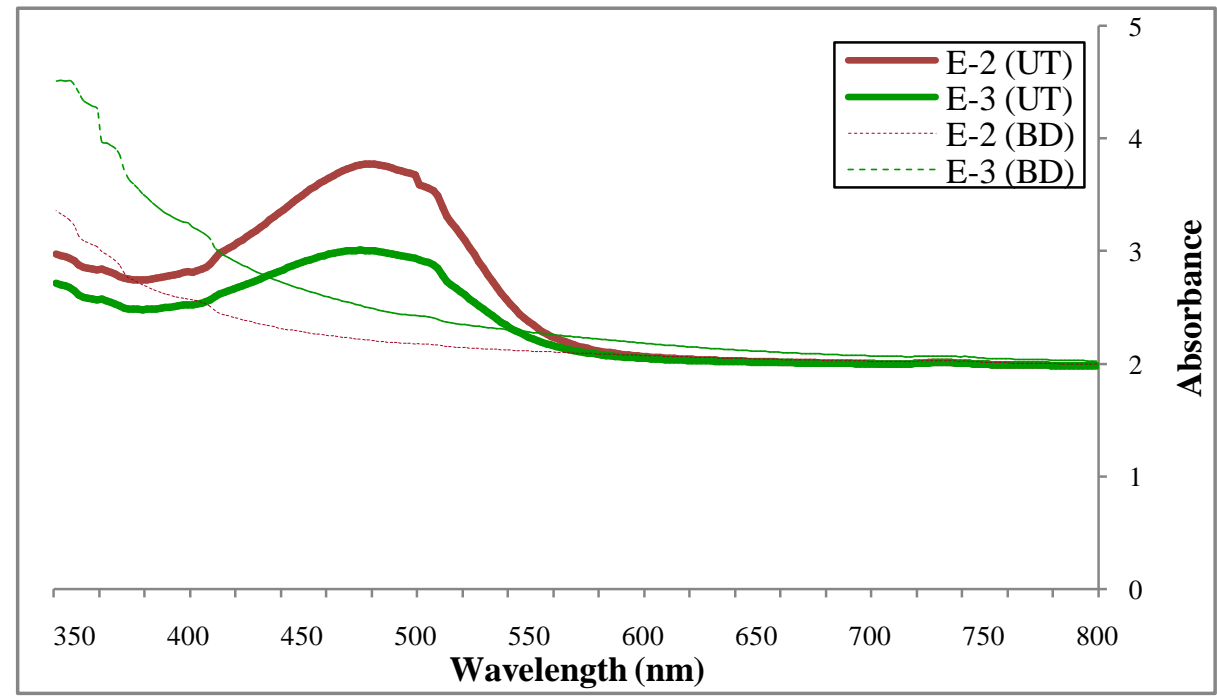

Figure 4 UV-Vis spectra of untreated (UT) and biodegraded (BD) DHEs.

decolourization and degradation of azo dyes (Singh et al., 2015). In the present study reductive enzyme activity and laccase enzyme activities were found higher as compared to other enzymes.

\subsection{Biodegradation analysis}

UV-Vis spectra of untreated and treated (biodegraded) DHEs showed disappearance of peaks in the visible region of the spectrum, indicated degradation of DHEs (Figure 4). Results of FTIR (Figure 5; Table 2) and HPLC (Figure 6; Table 3) analysis revealed that both the DHEs were decolourized with simultaneous degradation.

The FTIR spectra of DHEs, before and after degradation showed differences in the peaks (Figure 5; Table 2). Shifting of major peaks was found in biodegraded metabolite fractions of DHEs as compared to non degraded DHEs confirmed changes in the structural configuration of organic molecules present in the DHEs. Peaks at 3417 and $3433 \mathrm{~cm}^{-1}$ were found, which represent -OH stretching in untreated E-2 and E-3, respectively. This confirmed 

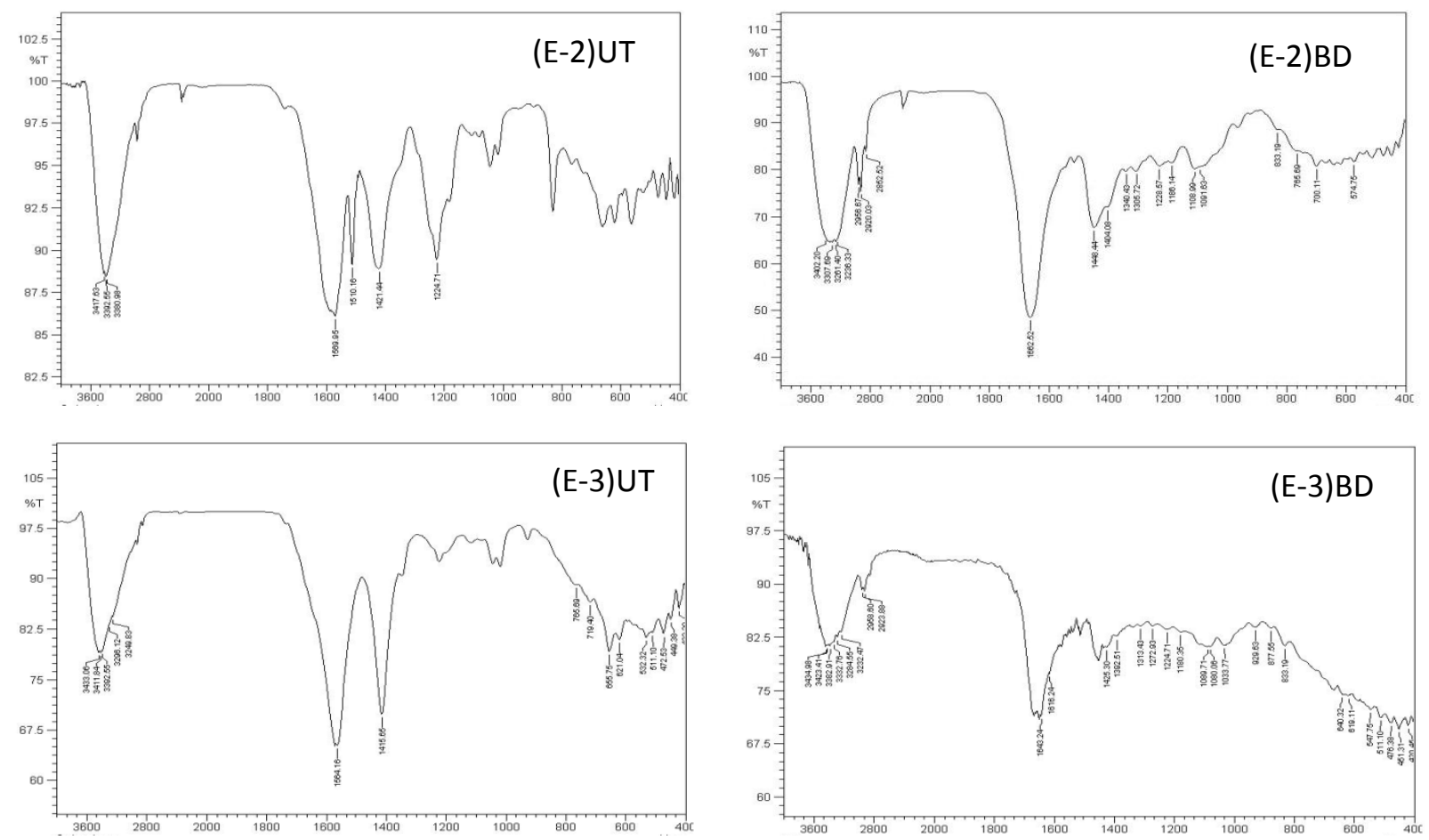

Figure 5 FTIR spectra of effluents. Untreated (UT) and Biodegraded (BD).

Table 2 FTIR spectral results of untreated (UT) and biodegraded (BD) DHEs.

\begin{tabular}{|c|c|c|c|c|c|c|c|}
\hline \multicolumn{4}{|c|}{$\mathrm{E}-2$} & \multicolumn{4}{|c|}{ E-3 } \\
\hline \multicolumn{2}{|c|}{ UT } & \multicolumn{2}{|c|}{$\mathrm{BD}$} & \multicolumn{2}{|c|}{ UT } & \multicolumn{2}{|c|}{$\mathrm{BD}$} \\
\hline Peak $\left(\mathrm{cm}^{-1}\right)$ & Bond & Peak $\left(\mathrm{cm}^{-1}\right)$ & Bond & Peak $\left(\mathrm{cm}^{-1}\right)$ & Bond & Peak $\left(\mathrm{cm}^{-1}\right)$ & Bond \\
\hline 3417.6 & OH Str & 3402.2 & OH Str & 3433.1 & OH Str & 3434.9 & OH Str \\
\hline 1569.9 & $\mathrm{~N}=\mathrm{N}$ Vib & 2920.0 & C-H Str & 1584.2 & $\mathrm{~N}=\mathrm{N}$ Vib & 2923.9 & C-H Str \\
\hline 1510.2 & $\mathrm{NO}_{2} \mathrm{Str}$ & 1448.4 & $\mathrm{CH}_{3}$ Def & 1415.7 & C-N Str & 1643.2 & $\mathrm{C}=\mathrm{O}$ Str \\
\hline 1421.4 & C-H Vib & 1404.1 & C-N Str & 1041.5 & $\mathrm{~S}=\mathrm{O}$ Str & 1425.3 & $\mathrm{CH}_{3}$ Def \\
\hline 1224.7 & C-N Str & 1340.4 & $\mathrm{~S}=\mathrm{O}$ Str & 927.7 & $\mathrm{C}=\mathrm{C}$ Def & 1392.5 & C-N Vib \\
\hline 1041.5 & $\mathrm{~S}=\mathrm{O}$ Str & 1305.7 & $\mathrm{~N}=\mathrm{N}-\mathrm{O}$ Str & 765.7 & C-H Def & 833.2 & C-H Def \\
\hline 669.3 & OH Def & 1228.6 & C-N Str & 719.4 & OH Def & 547.7 & Ring Def \\
\hline 565.1 & Ring Def & 1108.9 & C-OH Str & 511.1 & $\mathrm{NO}_{2}$ Band & 511.1 & $\mathrm{NO}_{2}$ Band \\
\hline 493.7 & $\mathrm{NO}_{2} \mathrm{Str}$ & 833.2 & C-H Def & 472.5 & $\mathrm{NO}_{2} \mathrm{Str}$ & 476.4 & $\mathrm{NO}_{2} \mathrm{Str}$ \\
\hline 474.5 & $\mathrm{NO}_{2} \mathrm{Str}$ & 700.1 & OH Def & 449.4 & C-N-C Band & 461.3 & C-N-C bend \\
\hline 437.8 & C-N-C Band & 574.7 & Ring Def & & & & \\
\hline
\end{tabular}

Def: Deformation; Vib: Vibration; Str: Stretching; Bend: Bending

the presence of phenolic compounds in the DHEs. Moreover, removal of azo bond and change in spectrum profile of all five DHEs, before and after degradation confirmed the degradation of both the DHEs. Disappearances of azo bond representative peaks from 1569 and $1584 \mathrm{~cm}^{-1}$ confirmed the cleavage of azo bond in E-2 and E-3 after degradation, respectively. Appearance of peak at $1108.9 \mathrm{~cm}^{-1}$ in the degraded metabolite fraction of E-2 suggests generation of aliphatic alcohol formation. Aliphatic $-\mathrm{CH}_{3}$

Journal of Experimental Biology and Agricultural Sciences http://www.jebas.org 
$\mathrm{mV}$

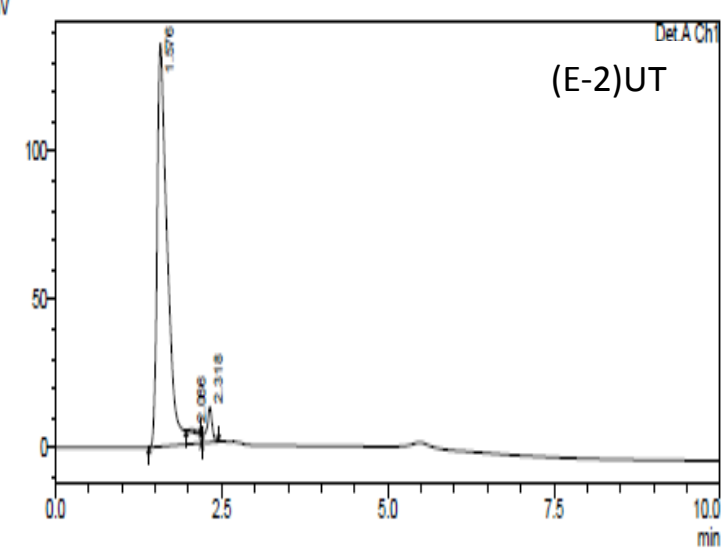

$\mathrm{mV}$

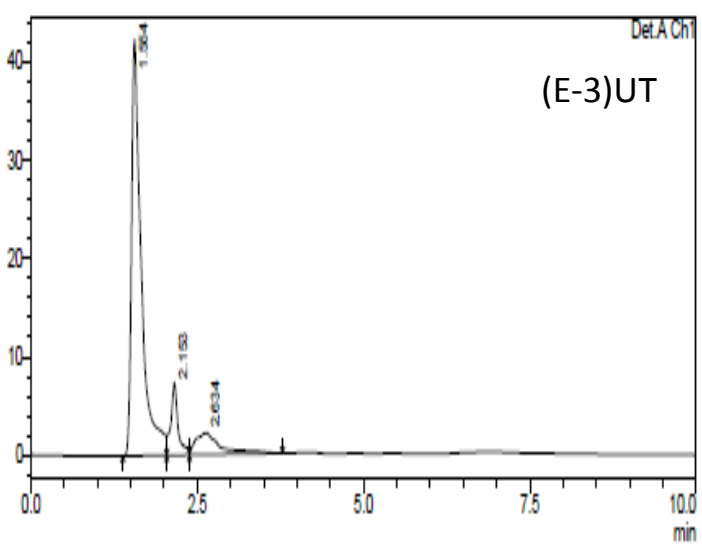

$\mathrm{mV}$

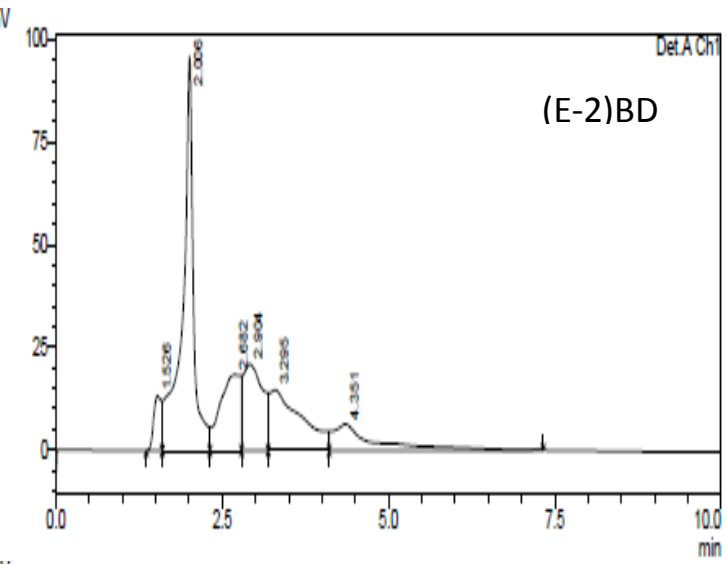

$\mathrm{mV}$

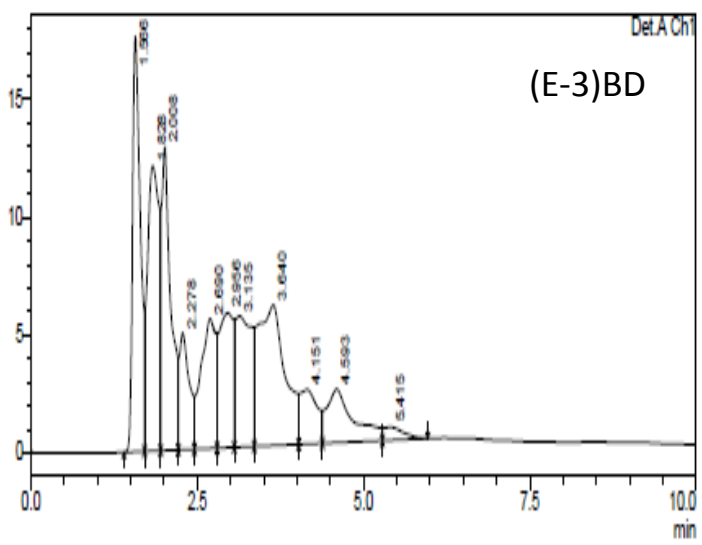

Figure 6 HPLC spectra of effluents. Untreated (UT) and Biodegraded (BD).

Table 3 HPLC elution profile of untreated (UT) and biodegraded (BD) DHEs.

\begin{tabular}{|c|c|c|c|c|}
\hline \multirow{3}{*}{ Peak number } & \multicolumn{4}{|c|}{ HPLC Peaks } \\
\hline & \multicolumn{2}{|c|}{ E-2 } & \multicolumn{2}{|c|}{ E-3 } \\
\hline & UT & $\mathrm{BD}$ & UT & $\mathrm{BD}$ \\
\hline 1 & 1.576 & 1.526 & 1.554 & 1.566 \\
\hline 2 & 2.066 & 2.006 & 2.153 & 1.828 \\
\hline 3 & 2.318 & 2.682 & 2.634 & 2.008 \\
\hline 4 & & 2.904 & & 2.278 \\
\hline 5 & & 3.295 & & 2.690 \\
\hline 6 & & 4.351 & & 2.956 \\
\hline 7 & & & & 3.135 \\
\hline 8 & & & & 3.640 \\
\hline 9 & & & & 4.151 \\
\hline 10 & & & & 4.593 \\
\hline 11 & & & & 5.415 \\
\hline
\end{tabular}

Journal of Experimental Biology and Agricultural Sciences http://www.jebas.org 
Table 4 Phytotoxicity and microbial toxicity study of untreated (UT) and biodegraded (BD) DHEs.

\begin{tabular}{|c|c|c|c|c|c|c|}
\hline \multirow{3}{*}{ DHEs } & \multirow{3}{*}{ Treatment } & \multirow{2}{*}{\multicolumn{3}{|c|}{$\begin{array}{c}\text { Phytotoxicity } \\
\text { Phaseolus mungo }\end{array}$}} & \multicolumn{2}{|c|}{ Microbial toxicity } \\
\hline & & & & & P. aeruginosa & Azotobacter sp. \\
\hline & & Germination (\%) & Root length $(\mathrm{cm})$ & Shoot length (cm) & \multicolumn{2}{|c|}{ Zone of inhibition (mm) } \\
\hline \multirow[t]{2}{*}{ E-2 } & UT & 0 & - & - & $19.0 \pm 0.2$ & $18.1 \pm 0.1$ \\
\hline & $\mathrm{BD}$ & 70 & $6.9 \pm 1.0$ & $8.6 \pm 2.4$ & $11.0 \pm 0.2$ & $10.0 \pm 0.1$ \\
\hline \multirow[t]{2}{*}{ E-3 } & UT & 0 & - & - & $22.2 \pm 0.2$ & $26.0 \pm 0.2$ \\
\hline & $\mathrm{BD}$ & 80 & $5.7 \pm 1.7$ & $12.2 \pm 2.2$ & $14.1 \pm 0.2$ & $12.1 \pm 0.3$ \\
\hline Control & - & 100 & $6.0 \pm 1.6$ & $13.0 \pm 3.2$ & NI & NI \\
\hline
\end{tabular}

NI: No inhibition, 10 seeds were dipped in $10 \mathrm{~mL}$ of UT and BD effluents and allowed to germinate at $32 \pm 2{ }^{\circ} \mathrm{C}$ temperature for 10 days. Further, $5 \mathrm{~mL}$ effluent was added on $4^{\text {th }}$ and $7^{\text {th }}$ day.

deformation peaks at 1448 to $1425 \mathrm{~cm}^{-1}$ and aromatic ring deformation peaks at 574 and $547 \mathrm{~cm}^{-1}$ frequencies were found in degraded metabolite fractions suggested aromatic ring deformation to aliphatic molecules of E-2 and E-3, respectively. Removal of metal and cleavage of azo bond followed by aromatic ring breakage to aliphatic one could be the intermittent important steps during degradation mechanism as both the DHEs were originated while manufacturing of metal complex dyes.

HPLC elution peaks of untreated and biodegraded DHEs were compared, which showed considerable differences in peak profile after degradation of DHEs (Figure 6; Table 3). Peaks of treated DHEs fractions were different in terms of number, height and area than the untreated DHE. Disappearance of major peaks with emergence of new peaks with different retention time was observed in case of both the DHEs. Major peaks were found at 1.57 and 1.55 RT in case of untreated E-2 and E- 3, respectively whereas treated DHEs showed differences in peak profile and majority of them were at higher RT than the peaks of untreated DHEs.

\subsection{Toxicity study}

Toxicity on plant was studied and none of the untreated DHEs showed any germination, whereas after treatment there were 70 and 80 germination with E-2 and E-3, respectively (Table 4). Reduced toxicity was observed on root and shoot lengths after treatment, irrespective of DHEs used in the study. Khandare et al. (2013) have reported reduction in phytotoxicity on $P$. mungo in terms of seed germination, length of plumule and length of radical after treatment of textile effluent.

Microbial toxicity study was carried out with Azotobacter and $P$. aeruginosa and results are shown in Table 4 . Microbial toxicity was found to be reduced in the range of $40-42 \%$ and $44-46 \%$ in case of E-2 and E-3, respectively with both the test organisms. Reduction in phyto and microbial toxicity at a considerable extent represent the treatment efficiency by the developed consortium for such a recalcitrant industrial waste.

\section{Conclusion}

The study proved the efficiency of the developed consortium towards the biodegradation of both the dye house wastes of quite diverse and complex nature. Considerable reduction in ADMI, BOD, COD, TOC, solids and metals suggested the possible use of the developed single consortium for treatment of different dye house wastes. The probable mechanism was cleavage of azo bond, deformation of aliphatic compounds and aromatic rings which resulted in degraded, decolourized, less toxic effluents, which can be released safely. Moreover, after microbial treatment, toxicity of original DHEs was considerably decreased on plants and bacteria. It also showed reduction in organic load in the DHEs. Such single consortial system increases the applicability of bioremediation strategy as single treatment machinery and could be scaled up for the treatment of a wide range of DHEs.

\section{Acknowledgement}

Authors are thankful to Department of Science and Technology (New Delhi) for providing financial support under DST WOS-A Scheme grant [Number SR/WOS A/LS-461/2013] for the proposed study and University Grants Commission (UGC) under UGC Emeritus Professor Fellowship [Number F.6-6/201517/EMERITUS-2015-17-GEN-7433 /(SA-II)] to senior author.

\section{Conflict of interest}

No potential conflict of interest was reported by the authors.

\section{References}

Agrawal S, Tipre D, Patel B, Dave S (2014) Optimization of triazo Acid Black 210 dye degradation by Providencia sp. SRS82 and elucidation of degradation pathway. Process Biochemistry 49: 110-119 doi:10.1016/j.procbio.2013.10.006.

Alizadeh N, Shariati S, Besharati N (2017) Adsorption of Crystal Violet and Methylene Blue on Azolla and Fig leaves modified 
with magnetite iron oxide nanoparticles. International Journal of Environmental Research 11: 197-206 doi:10.1007/s41742-0170019-1.

Balapure K, Jain K, Bhatt N, Madamwar D (2016) Exploring bioremediation strategies to enhance the mineralization of textile industrial wastewater through sequential anaerobicmicroaerophilic process. International Biodeterioration and Biodegradation 106: 97-105 doi:10.1016/j.ibiod.2015.10.008.

Bilal M, Adeel M, Rasheed T, Zhao Y, Iqbal H (2019) Emerging contaminants of high concern and their enzyme-assisted biodegradation: A review. Environment International 124: 336353 doi:10.1016/j.envint.2019.01.011.

Bilal M, Rasheed T, Iqbal $\mathrm{H}, \mathrm{Li} \mathrm{C}$, Wang $\mathrm{H}, \mathrm{Hu} \mathrm{H}$, Wang W, Zhang X (2018) Photocatalytic degradation, toxicological assessment and degradation pathway of CI Reactive Blue 19 dye, Chemical Engineering Research and Design 129:384-390 doi:10.1016/j.cherd.2017.11.040.

Cerron LM, Romero-Suarez D, Vera N, Ludena Y, Villena GK (2015) Decolorization of textile reactive dyes and effluents by biofilms of Trametes polyzona LMB-TM5 and Ceriporia sp. LMB-TM1 isolated from the Peruvian rainforest. Water, Air \& Soil Pollution 226: 235 (1-13) doi:10.1007/s11270-015-2505-4.

Dave SR, Dave RH (2009) Isolation and characterization of Bacillus thuringiensis for Acid red 119 dye decolourisation. Bioresource Technology 100: 249-253 doi:10.1016/j.biortech.2008.05.019.

Dave SR, Patel TL, Tipre DR (2015) Bacterial degradation of azo dye containing wastes. Microbial Degradation of Synthetic Dyes in Wastewaters, Environmental Scinece and Engineering, Springer International Publishing, Switzerland. doi:10.1007/9783-319-10942-8_3.

de Almeida EJR, Corso CR (2016) Acid Blue 161: Decolorization and toxicity analysis after microbiological treatment. Water, Air \& Soil Pollution 227: 468(1-8) doi:10.1007/s11270-016-3042-5.

Dhall P, Kumar R, Kumar A (2012) Biodegradation of sewage wastewater using autochthonous bacteria. Scientific World Journal 2012: 1-8 doi:10.1100/2012/861903.

Eaton AD, Clesceri LS, Greenberg AE, Franson MAH (1998) Standard methods for the examination of water and wastewater. $19^{\text {th }}$ ed. Washington, DC: American Public Health Association.

Forgacs E, Cserhati T, Oros G (2004) Removal of synthetic dyes from wastewaters: a review. Environment International 30: 953 971 doi:10.1016/j.envint.2004.02.001.
Ghosh A, Dastidar MG, Sreekrishnan TR (2017) Bioremediation of chromium complex dyes and treatment of sludge generated during the process. International Biodeterioration and Biodegradation 119: 448-460 doi:10.1016/j.ibiod.2016.08.013.

Hassan M, Hawkyard C (2002) Ferral-catalyzed ozonation of aqueous dyes in a bubble-column reactor. Catalysis Communications 3: 281-286.

He F, Hu W, Li Y (2004) Biodegradation mechanisms and kinetics of azo dye 4BS by a microbial consortium. Chemosphere 57: 293-301 doi:10.1016/j.chemosphere.2004.06.036.

Kadam AA, Telke AA, Jagtap SS, Govindwar SP (2011) Decolorization of adsorbed textile dyes by developed consortium of Pseudomonas sp. SUK1 and Aspergillus ochraceus NCIM 1146 under solid state fermentation. Journal of Hazardous Materials 189: 486-494 doi:10.1016/j.jhazmat.2011.02.066.

Khan Z, Jain K, Soni A, Madamwar D (2014) Microaerophilic degradation of sulphonated azo dye e Reactive Red 195 by bacterial consortium AR1 through co-metabolism. International Biodeterioration and Biodegradation 94: 167-175 doi:10.1016/j.ibiod.2014.07.002.

Khandare RV, Kabra AN, Kadam AA, Govindwar SP (2013) Treatment of dye containing wastewaters by a developed lab scale phytoreactor and enhancement of its efficacy by bacterial augmentation. International Biodeterioration and Biodegradation 78: 89-97 doi:10.1016/j.ibiod.2013.01.003.

Khehra M, Saini H, Sharma D, Chadha B, Chimni S (2005) Decolorization of various azo dyes by bacterial consortium. Dyes and Pigments 67: 55-61 doi:10.1016/j.dyepig.2004.10.008.

Kurade MB, Waghmode TT, Kagalkar AN, Govindwar SP (2012) Decolorization of textile industry effluent containing disperse dye Scarlet RR by a newly developed bacterial-yeast consortium BLGG. Chemical Engineering Journal 184: 33-41 doi:10.1016/j.cej.2011.12.058.

Lade HS, Waghmode TR, Kadam AA, Govindwar SP (2012) Enhanced biodegradation and detoxification of disperse azo dye Rubine GFL and textile industry effluent by defined fungalbacterial consortium. International Biodeterioration and Biodegradation 72: 94-107 doi:10.1016/j.ibiod.2012.06.001.

Li H, Liu F, Zhu M, Feng X, Zhang J, Yin H (2015) Structure and properties of Co-doped cryptomelane and its enhanced removal of $\mathrm{Pb}^{2+}$ and $\mathrm{Cr}^{3+}$ from wastewater. Journal of Environmental Sciences 34: 77-85 doi:10.1016/j.jes.2015.02.006.

Pandey A, Singh P, Iyengar L (2007) Bacterial decolorization and degradation of azo dyes. International Biodeterioration and Biodegradation 59: 73-84 doi:10.1016/j.ibiod.2006.08.006. 
Patel DK Tipre DR, Dave SR (2017b) Enzyme mediated bacterial biotransformation and reduction in toxicity of $1: 2$ chromium complex AB193 and AB194 dyes. Journal of Taiwan Institute of Chemical Engineering 77: 1-9 doi:10.1016/j.jtice.2017.02.027.

Patel DK, Tipre DR, Dave SR (2017a) Selection and development of efficient consortia for decolorization of metal complex dyes. Toxicological and Environmental Chemistry 99: 252-264 doi:10.1080/02772248.2016.1178264.

Patel TL, Patel BC, Kadam AA, Tipre DR, Dave SR (2015) Application of novel consortium TSR for treatment of industrial dye manufacturing effluent with concurrent removal of ADMI, COD, heavy metals and toxicity. Water Science and Technology 71: 1293-1300 doi:10.2166/wst.2015.073.

Raper E, Stephenson T, Anderson D, Fisher R, Soares A (2018) Industrial wastewater treatment through bioaugmentation. Process Safety and Environmental Protection, 118, 178-187, doi:10.1016/j.psep.2018.06.035.

Saratale RG, Gandhi SS, Purankar MV, Kurade MB, Govindwar SP, Oh SE, Saratale GD (2012) Decolorization and detoxification of sulfonated azo dye C.I. Remazol Red and textile effluent by isolated Lysinibacillus sp. RGS. Journal of Bioscience and Bioengineering 6: 65-667 doi:10.1016/j.jbiosc.2012.12.009.

Shah MP, Patel KA, Nair SS, Darji AM (2013) Environmental bioremediation of dyes by Pseudomonas aeruginosa ETL-1 isolated from final effluent treatment plant of Ankleshwar. American Journal of Microbiological Research 1: 74-83 doi: 10.12691/ajmr-1-4-3.

Shah PD, Dave SR, Rao MS (2012) Enzymatic degradation of textile dye Reactive Orange 13 by newly isolated bacterial strain Alcaligenes faecalis PMS-1. International Biodeterioration and Biodegradation 69: 41-50 doi:10.1016/j.ibiod.2012.01.002.
Sheth NT, Dave SR (2010) Enhanced biodegradation of Reactive Violet 5R manufacturing wastewater using down flow fixed film bioreactor. Bioresource Technology 101: 8627-8631 doi:10.1016/j.biortech.2010.06.106.

Singh RL, Singh PK, Singh RP (2015) Enzymatic decolorization and degradation of azo dyes - A review. International Biodeterioration and Biodegradation 104: 21-31 doi:10.1016/j.ibiod.2015.04.027.

Stolz A (2001) Basic and applied aspects in the microbial degradation of azo dyes. Applied Microbiology and Biotechnology 56: 69-80.

Swati M, Sinha SS, Singh M (2017) Microbial decolorization and detoxification of emerging environmental pollutant: Cosmetic hair dyes. Journal of Hazardous Materials 338: 356-363 doi:10.1016/j.jhazmat.2017.05.034.

Tehrani-Bagha A, Mahmoodi N, Menger F (2010) Degradation of a persistent organic dye from colored textile wastewater by ozonation. Desalination 260: 34-38 doi:10.1016/j.desal.2010.05.004.

Vikrant K, Giri BS, Roy K,Kim KH, Rai BN, Singh RS (2018) Recent advancements in bioremediation of dye: Current status and challenges. Bioresource Technology 253 10.1016/j.biortech.2018.01.029.

Zablocka-Godlewska E, Przystas W, Grabinska-Sota E (2015) Dye decolourisation using two Klebsiella strains. Water, Air \& Soil Pollution 225: 1846 (1-15) doi:10.1007/s11270-014-2249-6.

Zhang W, Liu W, Zhang J, Zhao H, Zhang Y, Quan X, Jin Y (2012) Characterisation of acute toxicity, genotoxicity and oxidative stress posed by textile effluent on zebrafish. Journal of Environmental Sciences 24: 2019-2027 doi:10.1016/S10010742(11)61030-9.

Journal of Experimental Biology and Agricultural Sciences http://www.jebas.org 